\title{
Human-Soil Relations are Changing Rapidly: Proposals from SSSA's Cross-Divisional Soil Change Working Group
}

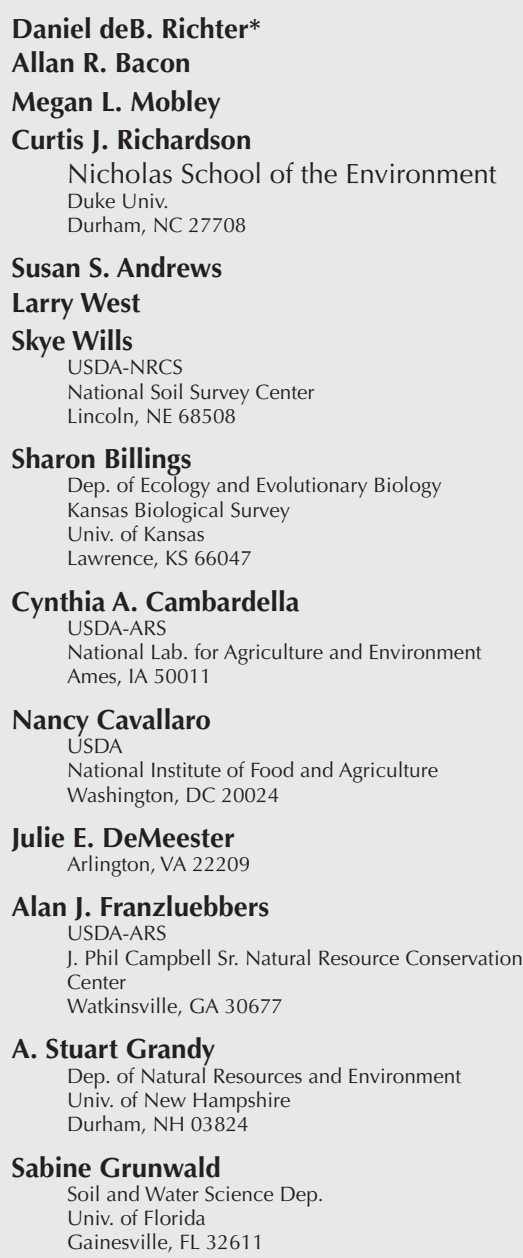

Joel Gruver

School of Agriculture

Western Illinois Univ.

Macomb, IL 61455

Anthony S. Hartshorn

Dep. of Geology and Environmental Science

James Madison Univ.

Harrisonburg, VA 22807

Henry Janzen

Agriculture and Agri-Food Canada

Lethbridge Research Centre

Lethbridge, AB, T1J 4B1 Canada

Marc G. Kramer

USDA Forest Service

Portland, OR 97204

Jagdish K. Ladha

IRRI

New Delhi 110012, India

Kate Lajtha

Dep. of Crop and Soil Science

Oregon State Univ.

Corvallis, OR 97331

\section{Garrett C. Liles}

Dep. of Land, Air, and Water Resources

Univ. of California

Davis, CA 95616

Daniel Markewitz

Warnell School of Forestry and Natural Resources

Univ. of Georgia

Athens, GA 30602

Patrick J. Megonigal

Smithsonian Environmental Research Center

Smithsonian Institution

Washington, DC 20013

Ahmet R. Mermut

Dep. of Soil Science

Univ. of Saskatchewan

Saskatoon, SK, S7N 5 A2 Canada
Craig Rasmussen

Dep. of Soil, Water, and Environmental Science

Univ. of Arizona

Tucson, AZ 85721

David A. Robinson

Centre for Ecology and Hydrology

Environmental Centre Wales

Bangor, Gwynedd, LL57 2UW UK

Pete Smith

School of Biological Sciences

Univ. of Aberdeen

Aberdeen AB24 3UU UK

Cynthia A. Stiles

USDA-NRCS

Pacific Islands Area State Office

Honolulu, HI 96850

Robert L. Tate III

Dep. of Environmental Sciences

Rutgers Univ.

New Brunswick, NJ 08901

Aaron Thompson

Dep. of Crop and Soil Sciences

Univ. of Georgia

Athens, GA 30602

Arlene J. Tugel

USDA-NRCS

Las Cruces, NM 88003

Harold van Es

Dep. of Crop and Soil Sciences

Dep. of Crop

Ithaca, NY 14853

Dan Yaalon

Inst. of Earth Sciences

Hebrew Univ.

Jerusalem, Israel 91904

Ted M. Zobeck

USDA-ARS

Cropping Systems Research Lab. Lubbock, TX 79415

A number of scientists have named our age the Anthropocene because humanity is globally affecting Earth systems, including the soil. Global soil change raises important questions about the future of soil, the environment, and human society. Although many soil scientists strive to understand human forcings as integral to soil genesis, there remains an explicit need for a science of anthropedology to detail how humanity is a fully fledged soil-forming factor and to understand how soil change affects human well being. The development and maturation of anthropedology is critical to achieving land-use sustainability and needs to be nurtured by all soil disciplines, with inputs from allied sciences and the humanities,. The Soil Science Society of America (SSSA) has recently approved a cross-divisional Working Group on Soil Change, which aims to advance the basic and applied science of anthropedology, to facilitate networks of scientists, long-term soil field studies, and regional databases and modeling, and to engage in new modes of communications about human-soil relations. We challenge all interested parties, especially young scientists and students, to contribute to these activities and help grow soil science in the Anthropocene.

Soil Sci. Soc. Am. J. 75:2079-2084

Posted online 27 Sept. 2011

doi:10.2136/sssaj2011.0124

Received 4 April 2011

*Corresponding author (drichter@duke.edu).

(C) Soil Science Society of America, 5585 Guilford Rd., Madison WI 53711 USA

All rights reserved. No part of this periodical may be reproduced or transmitted in any form or by

any means, electronic or mechanical, including photocopying, recording, or any information storage and retrieval system, without permission in writing from the publisher. Permission for printing and for

reprinting the material contained herein has been obtained by the publisher. 
$S_{\mathrm{d} d}^{\mathrm{oil}}$ oil science and pedology are sciences of change. In the past, peologists focused mainly on natural soil-forming factors and processes, i.e., on soil changes that take place on the natural pedogenic clock, spanning centuries to thousands and millions of years (Jenny, 1941; Simonson, 1959; Cline, 1961; Buol et al., 2003; Schaetzl and Anderson, 2005). The venerable soil scientist E.W. Hilgard (1860), when asked the question "What is soil?", stated clearly his abiding interest in "the virgin soil", soil not influenced by humanity.

The natural-body orientation of soil science and pedology has recently motivated Dudal et al. (2002) to critique our science by asking simply, "Are we a soil-forming factor short?" Indeed, many soil and environmental scientists now recognize the extent, complexity, and intensity of human influences on soil (Richter and Markewitz, 2001; Galbraith, 2006; Dazzi et al., 2009). Some strive to understand human alterations of soil not only as a soil disturbance but as an integral part of soil genesis. Human forcings, both planned and capricious, are redirecting the course of the natural forces that have long driven natural soil genesis. There is great need for a science of anthropedology to more fully understand humanity as a soil-forming factor.

Here we use broad definitions of soil, ecosystems, pedology, and soil science to consider how humanity is changing the soil and soil-environment interactions and how soil change is impacting humanity. For good reason, some geologists have suggested naming our epoch the Anthropocene (Crutzen, 2002; Zalasiewicz et al., 2011, Anonymous, 2011), an idea whose roots originated in the 19th and 20th centuries (Marsh, 1874; Vernadsky, 1945; Osborn, 1948). Humanity has rapidly become Earth's chief agent of soil change and we are substantially altering the soil with welldocumented effects on erosion and sedimentation (Hooke, 2000; Wilkinson, 2005), the C cycle (Houghton, 2007), the $\mathrm{N}$ cycle (Johnson and Lindberg, 1992; Vitousek et al., 1997), the P cycle (Filippelli, 2008; Richardson, 2008), climate systems (Robertson et al., 2000), and hydrology, salinity, and water quality (Postel et al., 1996; Pitman and Läuchli, 2002). Although we are greatly concerned about human-forced soil change as a degradation of natural capital (Palm et al., 2007; Robinson et al., 2009), humans also alter soils in ways that are beneficial to humanity and the environment. Excellent examples include ecosystem restoration (Craft et al., 2003) and soil amendments such as liming (Farina et al., 2000). In fact, if humanity is to improve environmental management in the coming few decades, we must manage a great diversity of soils much more positively (Buol et al., 2003; Schaetzl and Anderson, 2005; Johnson, 2005; Palm et al., 2007; Dominati et al., 2010).

Soils have long memories; they quietly record the history of natural and human impacts, with new changes laid down on those from the past (Targulian and Goryachkin, 2004). To predict how human forcings influence soils locally or globally, we need a much better understanding of the legacies of human impacts on soils and of soil influences on humanity (Showers, 2006; Ramankutty et al., 2008). In particular, we know far too little about the rates of soil change in response to land management, about soil resilience to historic and contemporary management, and about soil response rates to improved land management and changes in climates.
Today, more than half of the Earth's soils are cultivated for food crops, grazed or managed for domesticated animals, or periodically logged for wood (Ellis, 2011). In addition, soils are manipulated for residential, industrial, transportation, and recreational development; exposed to many and various disturbances that alter their hydrology, plant community composition, and nutrient cycling; chemically contaminated; used for waste disposal; and subject to climate change. Each of these alterations of soils has reciprocal influences on humanity that are too rarely explored.

Two dramatic examples in the United States of reciprocal impacts of large-scale anthropogenic soil transformations and human well-being are the Dust Bowl of the 1930s and wetland drainage. The Dust Bowl resulted from a combination of problems including large-scale misuse of land and decadal climate shifts. It displaced more than 2.5 million people from their homes and farms. A full understanding of this land and soil crisis includes not only scientific investigations such as the new geospatial historical assessment "Scaling the Dust Bowl" by Geoff Cunfer (2008), but also the novel Grapes of Wrath by John Steinbeck (1940), and even the controversial environmental history Dust Bowl by Donald Worster (2004; see also Trimble, 2010). The reciprocal effects of large-scale land transformations and humanity are also seen in our second example of wetland drainage. In the United States, about 45 million ha of hydric wetland soils have been drained and converted to agricultural and residential uses (Dahl, 2006). Like nearly everywhere land is drained, agricultural and forestry productivity have been impressive, and the historian Fernand Braudel (1974) has described well the far-reaching effects of drainage on landscapes, economics, and culture. But as demonstrated by the recent Mississippi River floods of 2011, drainage alters the hydrology at a range of spatial and temporal scales, and even drained land is periodically at odds with larger scale Earth processes such as flooding.

Such interactions of humanity and soil change are part of the process of soil and landscape domestication (Hole, 1974) and the creation of anthropogenic biomes (Ellis and Ramankutty, 2008). To better understand this process of global soil change (Arnold et al., 1990), soil scientists need broad ties across the sciences and the humanities. Specifically, soil scientists need new alliances with anthropologists, historians, philosophers, economists, engineers, archaeologists, social scientists, geographers, and psychologists to more fully understand human-soil interactions.

\section{WHY IS SOIL CHANGE IMPORTANT TO SSSA AND TO SOCIETY AT LARGE?}

The history of agricultural management during the past 50 yr illustrates well the vast productivity of soils worldwide, as agricultural outputs grew to feed a doubling of the human population. This period of the Green Revolution witnessed a tripling in global crop production and the most rapid improvement in the average human diet in history (Richter et al., 2007).

Even still, many of society's most important scientific questions concern the immediate future of Earth's changing soils, and these questions need to be articulated clearly and forcefully by soil 
scientists. For example, how can we further expand crop production in the coming decades, keeping pace with human needs and demands for food and other products while improving environmental quality? Land management is already pressing hard on soils, freshwater and marine resources, the atmosphere, and ecosystem services. Many scientists and managers are deeply concerned about the future functioning and health of soils and ecosystems, including in the context of climate change (National Research Council, 2010).

Today we face larger challenges than those faced by the Green Revolutionaries of the mid-20th century, for our challenges are both quantitative and qualitative. The question of how we can manage more production from soils and ecosystems but at the same time improve soil and ecosystem services can hardly be answered by soil science alone (Daily, 1997). This question demonstrates why contemporary soil science needs to work closely with allied sciences and the humanities.

There are many important soil frontiers for young scientists to explore and a most important measure of SSSA's success must be based on its attraction of the best scientists to quantify how and why soils are changing in local and global systems and in relation to the wider environment. Understanding soil's resistance and resilience (Greenland and Szablocs, 1994; Holling, 1996; Seybold et al., 1999), thresholds (Chadwick and Chorover, 2001; Bestelmeyer, 2006), early warning indicators, and hystereses are all critical to predicting soil change. Soil's vulnerability (and resistance) to change forced by land use, pollution, climate, or natural vegetation succession must be quantified and predictable.

The SSSA has a special responsibility not only to attract high quality students, but to promote high-quality research opportunities and help integrate scientific results in policy analysis and decision making. Specific issues that require soil expertise can hardly be more compelling. Included are questions about: sustaining and improving food, fiber, and bioenergy production systems; minimizing greenhouse gas emissions; maintaining more balanced soil $\mathrm{C}$ cycles, diminishing wind and water erosion and sedimentation, cycling nutrients and water more efficiently, improving water quality, preserving biodiversity and soil organic matter, and preventing or mitigating natural catastrophes such as flooding and landslides (Janzen et al., 2011). Given the acceleration of global soil change, the SSSA must continually address these soil issues with vigor and persuasive communication with scientists and non-scientists alike, describing the inseparable coupling of soil with water, air, climate, and the fate of civilization itself.

\section{PROPOSALS FOR A CROSS-DIVISIONAL SSSA AGENDA}

Although soil science is interdisciplinary (Cline, 1961), anthropedology must cast an especially wide net to address basic and applied objectives and interact extensively with the environmental, ecological, and earth sciences, social sciences (Tugel et al., 2005; Wilding and Lin, 2006), and the humanities (Showers, 2006; McNeill and Winiwarter, 2006). New synergies can derive from projects that span the disciplines and divisions of SSSA and that involve members of other professional societies (Wilding and Lin, 2006). Contemporary soil science must embrace all human relations with soils, a breadth that can help us articulate more fully how soils are the basis for sustaining civilization.

To stimulate greater SSSA discussion across divisions about the challenges faced by contemporary soil science, a cross-divisional Soil Change Working Group was formally launched within SSSA in 2009. This working group fosters interdisciplinary collaboration on soil issues affected by human forcings. Documents describing the mission, suggested activities, functions, and working group by-laws were prepared for the group's first meeting in Pittsburgh, PA, led by Arlene Tugel and Susan Andrews.

In 2010, at SSSA's Long Beach meetings, the working group sponsored a symposium entitled "Soil Change: Management Practices and Policy, featuring invited presentations by Henry Janzen and Karl Glasener on the science and policy of soil change, followed by a panel discussion with Julie DeMeester, Daniel Richter, Robert L. Tate III, and Harold van Es. The S1 Soil Physics and S5 Pedology divisions organized symposia entitled, "Soil Change: Characterization and Modeling Across Scales" and "Anthropogenic Soil Change: A New Frontier for Pedologists." Since the meetings, the Soil Change Working Group has created a web site (www.soils.org/about-society/soil-change; verified 22 Aug. 2011) and drafted this narrative to help advance their agenda.

The Soil Change Working Group challenges all interested parties to participate as it initiates three activities to advance: (i) a more explicit science of human-soil relations, i.e., anthropedology; (ii) greater networking of researchers, research sites, landscape-scale data sets, and models to quantify global soil change; and (iii) new forms of communication that articulate the importance of soil, soils research, and human-soil relations. To accomplish these tasks, the SSSA Soil Change Working Group will work jointly with the International Union of Soil Sciences (IUSS) Working Group on Global Soil Change and with individuals and groups from other professional societies, e.g., the American Association for the Advancement of Science, the American Geophysical Union, the National Cooperative Soil Survey, and the Ecological Society of America. The joint SSSA-IUSS activities in the history, philosophy, and sociology of soil science serve as a model for cooperation (www.iuss.org/ Newsletter_\%20Number\%2018.pdf; verified 22 Aug. 2011). Some detail describing these three agenda activities follow:

\section{Anthropedology}

The SSSA working group will draw on expertise from across SSSA divisions to help advance the science of anthropedology, the basic and applied science of how humans change soils and soil interactions with the wider environment and how soil changes impact humanity. With natural soil bodies becoming the parent material for human-altered soil systems (Yaalon and Yaron, 1966), all soil disciplines need to more fully integrate humanity within the concept of soil and soil change (Bidwell and Hole, 1965; Amundson and Jenny, 1991; Dudal et al., 2002; Richter, 2007). 
A more explicit understanding of anthropedology serves several aims: (i) ensuring the sustainability of soil outputs of food, fiber, bioenergy, and all vital ecosystem services that support the well-being of humanity; (ii) minimizing adverse impacts of soil management on the environment, especially its biodiversity and the functioning of the atmosphere, hydrosphere, and biosphere; (iii) conserving and restoring high-quality examples of natural soil bodies that are otherwise at risk of extinction (Amundson et al., 2003); and (iv) fostering new unifying theories and understanding of anthropedology and human-soil relations. All divisions of SSSA can contribute to and gain from anthropedology because humanity significantly influences soil physical, chemical, and biological features and functions; soil fertility and plant nutrition; pedogenesis; soil-water management and conservation; forest, range, and wildland soils; nutrient management and cycles; soil mineralogy; wetland soils; and interactions between soils and environmental quality.

\section{Networking}

The new science of anthropedology requires the networking of researchers with varied expertise and a networking of longterm, local field research sites, extensive databases, and modeling.

At the local scale of individual management units, i.e., farmers' fields and foresters' stands, hundreds of field experiments, known as long-term soil experiments (LTSEs), attempt to demonstrate directly and precisely how soil properties and functions respond to management regimes across annual to decadal time scales (Debreczeni and Körschens, 2003; Richter et al., 2007; Janzen, 2009; Schillinger, 2011). The Soil Change Working Group will promote the research of these long-running field studies by encouraging and coordinating: (i) meta-analyses of soil-change data from across LTSEs to address critical management and scientific questions about sustainable soil management (e.g., about production trends, $\mathrm{C}$ and nutrient cycling, and physical, chemical, and biological processes contributing to on- and off-site effects of management); (ii) new hypothesis-driven research about soil sustainability, including new sampling, analyses of soil archives, and modeling and decision-tool development for explanatory and predictive purposes (Smith et al., 1997, 2000); and (iii) establishment of new LTSEs to respond to emerging issues in land management and soil and environmental science.

At larger spatial scales of landscapes, regions, and the globe, opportunities for estimating and predicting soil change are many and diverse. Assessments of landscape-scale soil change include data set assembly, meta-analyses, and large-scale soil-change modeling. A number of efforts to harmonize and assess soil properties using digital soil mapping techniques are well underway. The NRCS is using new geospatial methods to better analyze its extensive soil survey data, including historic soil data (the National Cooperative Soil Characterization Database). The NRCS has also launched the "Rapid Assessment of U.S. Soil Carbon for Climate Change and Conservation Planning" to be based on 35,000 new sampling sites and has created a new Soil Ecology Branch at the National Soil Survey Center focused on soil-change issues. The National Ecological Observatory Network, Critical Zone
Exploratory Network and Critical Zone Observatories (CZEN and CZO), and SoilTrec programs each represent ambitious new efforts to research and reconceptualize the Earth's surficial systems, efforts supported both in the United States and abroad (Wilding and Lin, 2006). The NRCS, National Park Service, ARS, and other federal agencies are documenting land management effects on dynamic soil properties (Tugel et al., 2008), and the USGS continues to build its large, geographically explicit geochemistry databases (minerals.cr.usgs.gov/projects/geochem_database/; verified 22 Aug. 2011). In the United Kingdom and Belgium, largescale and policy-relevant soil sampling has been conducted for several decades (Emmett et al., 2010; Goidts and van Wesemael, 2007); these approaches aim to detect regional changes in acidity, C content, heavy metals, and metal chemistry. In the United States, research-driven projects are assessing soil $\mathrm{C}$ changes across large landscapes (Sabine Grunwald, personal communication, 2010) and across research sites (National Soil Carbon Network). The Soil Change Working Group can serve as a forum for how to better combine disparate data sets in meta-analyses and regional assessments of changes in soil properties and processes (e.g., Franzluebbers and Follett, 2005). Integration of large-scale data sets and modeling (e.g., using spatiotemporal soil data, remotesensing-derived environmental data, digital soil mapping, soil sensor data, and environmental geographic information system data) can benefit both soil science and land management decision making (Grunwald, 2006, 2009). Such data-rich projects are developing quickly, driven in part by technological advances.

Technological advances also impact operational applications of soil management. Various tools have been developed to assess changes in soil quality and function, for example, the Soil Management Assessment Framework (Andrews et al., 2004) and the Cornell Soil Health Test program (Idowu et al., 2009); many more are being developed. Regional data and information can now be efficiently delivered by iPhone and other mobile devices that can circulate large and complex geospatial data to land managers, scientists, and the public (Beaudette and O'Geen, 2010). Increasingly sophisticated tools that are useable on all continents may greatly improve soil's ability to produce recurring streams of food, fiber, bioenergy, and ecosystem services.

\section{Communication}

The cross-divisional working group will use a variety of communication and education tools to articulate how soils are central to human well-being and the environment. The working group can be a test bed for exploring new ways of communicating this urgent message, e.g., by promoting campaigns to write opinion-editorials, commentaries, and blogs (Yaalon, 2000, 2007; Robertson, 2008; Richter et al., 2009; Richter and Mobley, 2009; Grandy et al., 2010; Billings et al., 2010; Robinson and Lebron, 2010). These efforts can draw from the breadth of SSSA membership, articulating clear text, stories, and visual images for the public and for society's leaders, policymakers and analysts. Increasing the influence of soil scientists will happen only if more of us take definitive steps to effectively communicate the impor- 
tance of soils and soils research, the many important opportunities available for students and young scientists, and the need for policy-instructive recommendations on issues related to soil resources. This means motivating greater communication from more individuals across the SSSA and requires more coordination among the divisions of SSSA and between SSSA and other major organizations in environmental science and policy.

\section{IMPORTANT CHALLENGES AHEAD}

In 1937, the geographer Carl Sauer sharply questioned humanity's future and observed that humanity had "not yet learned the difference between yield and loot” (Sauer, 1937). Whether we can significantly move human-soil relations from exploitation and loot toward sustainability is a more urgent question now than ever before and can resonate widely with soil scientists, land managers, and the general public. Given the rushing pace of soil change in the Anthropocene, we must learn the difference between yield and loot in the coming decades and adjust our uses of soils accordingly. The stakes are high, for soil and the biosphere and for humanity. If managed well, soils offer humanity bountiful and renewing economic, environmental, social, and cultural values. If managed poorly, soils will be unable to deliver their many services that are essential for an optimistic future.

We challenge all interested individuals to contribute to this soils forum and to help improve understanding and management of soils now and in the future.

\section{REFERENCES}

Amundson, R., Y. Guo, and P. Gong. 2003. Soil diversity and land use in the United States. Ecosystems 6:470-482. doi:10.1007/s10021-002-0160-2

Amundson, R., and H. Jenny. 1991. The place of humans in the state factor theory of ecosystems and their soils. Soil Sci. 151:99-109. doi:10.1097/00010694199101000-00012

Andrews, S.S., D.L. Karlen, and C.A. Cambardella. 2004. The soil management assessment framework: A quantitative soil quality evaluation method. Soil Sci. Soc. Am. J. 68:1945-1962. doi:10.2136/sssaj2004.1945

Anonymous. 2011. The human epoch. Nature 473:254. doi:10.1038/473254a

Arnold, R.W., I. Szabolcs, and V.O. Targulian. 1990. Global soil change. Int. Inst. Appl. Syst. Anal., Laxenburg, Austria.

Beaudette, D.E., and A.T. O'Geen. 2010. An iPhone application for on-demand access to digital soil survey information. Soil Sci. Soc. Am. J. 74:16821684. doi:10.2136/sssaj2010.0144N

Bestelmeyer, B.T. 2006. Threshold concepts and their use in rangeland management and restoration: The good, the bad, and the insidious. Restor. Ecol. 14:325-329. doi:10.1111/j.1526-100X.2006.00140.x

Bidwell, O.W., and F.D. Hole. 1965. Man as a factor in soil formation. Soil Sci. 99:65-72. doi:10.1097/00010694-196501000-00011

Billings, S.A., J. Lichter, S.E. Ziegler, B.A. Hungate, and D.deB. Richter. 2010. A call to investigate drivers of soil organic matter retention vs. mineralization in a high $\mathrm{CO}_{2}$ world. Soil Biol. Biochem. 42:665-668. doi:10.1016/j. soilbio.2010.01.002

Braudel, F. 1974. The Mediterranean and the Mediterranean world in the age of Philip II. Harper and Row, New York.

Buol, S.A., R.J. Southard, R.C. Graham, and P.A. McDaniel. 2003. Soil genesis and classification. Blackwell Publ., Oxford, UK.

Chadwick, O.A., and J. Chorover. 2001. The chemistry of pedogenic thresholds. Geoderma 100:321-353. doi:10.1016/S0016-7061(01)00027-1

Cline, M.G. 1961. The changing model of soil. Soil Sci. Soc. Am. Proc. 25:442446. doi:10.2136/sssaj1961.03615995002500060009x

Craft, C.B., J.P. Megonigal, S.W. Broome, J. Cornell, R. Freese, R.J. Stevenson, L. Zheng, and J. Sacco. 2003. The pace of ecosystem development of constructed Spartina alterniflora marshes. Ecol. Appl. 13:1417-1432. doi:10.1890/02-5086

Crutzen, P.J. 2002. Geology of mankind. Nature 415:23. doi:10.1038/415023a

Cunfer, G. 2008. Scaling the Dust Bowl. p. 95-121. In A.K. Knowles and A. Hillier (ed.) Placing history: How maps, spatial data, and GIS are changing historical scholarship. ESRI Press, Redlands, CA.

Dahl, T.E. 2006. Status and trends of wetlands in the conterminous United States 1998 to 2004. U.S. Fish Wildlife Serv., Washington, DC.

Daily, G. (ed.). 1997. Nature's services: Societal dependence on natural ecosystems. Island Press, Washington, DC.

Dazzi, C., G. Lo Papa, and V. Palermo. 2009. Proposal for a new diagnostic horizon for WRB Anthrosols. Geoderma 151:16-21. doi:10.1016/j. geoderma.2009.03.013

Debreczeni, K., and M. Körschens. 2003. Long-term field experiments of the world. Arch. Agron. Soil Sci. 49:465-483. doi:10.1080/036503403100 01594754

Dominati, E., M. Patterson, and A. Mackay. 2010. A framework for classifying and quantifying the natural capital and ecosystem services of soils. Ecol. Econ. 69:1858-1868. doi:10.1016/j.ecolecon.2010.05.002

Dudal, R., F. Nachtergaele, and M.F. Purnell. 2002. The human factor of soil formation. Pap. 93. In World Congr. of Soil Sci., 17th, Bangkok, Thailand [CD-ROM]. 14-21 Aug. 2002. Soil and Fert. Soc. of Thailand, Bangkok.

Ellis, E.C. 2011. Anthropogenic transformation of the terrestrial biosphere. Philos. Trans. R. Soc. A 369:1010-1035. doi:10.1098/rsta.2010.0331

Ellis, E.C., and N. Ramankutty. 2008. Putting people on the map: Anthropogenic biomes of the world. Front. Ecol. Environ 10.1890/070062.

Emmett, B.A., B. Reynolds, P.M. Chamberlain, E. Rowe, D. Spurgeon, S.A. Brittain, et al. 2010. Soils report from 2007. Countryside Surv. Tech. Rep. 9.07. Ctr. Ecol. Hydrol., Wallingford, UK.

Farina, M.P.W., P. Channon, and G.R. Thibaud. 2000. A comparison of strategies for ameliorating subsoil acidity: II. Long-term soil effects. Soil Sci. Soc. Am. J. 64:652-658. doi:10.2136/sssaj2000.642652x

Filippelli, G.M. 2008. The global phosphorus cycle: Past, present, and future. Elements 4:89-95. doi:10.2113/GSELEMENTS.4.2.89

Franzluebbers, A.J., and R.F. Follett. 2005. Greenhouse gas contributions and mitigation potential in agricultural regions of North America: Introduction. Soil Tillage Res. 83:1-8. doi:10.1016/j.still.2005.02.020

Galbraith, J.M. 2006. ICOMAND: International Committee on Anthropogenic Soils. Available at clic.cses.vt.edu/icomanth/ (accessed 27 July 2007; verified 22 Aug. 2011). Virginia Polytech. State Univ., Blacksburg.

Goidts, E., and B. van Wesemael. 2007. Regional assessment of the changes in soil organic carbon stocks of agricultural soils in southern Belgium between 1955 and 2005. Geoderma 141:341-354. doi:10.1016/j. geoderma.2007.06.013

Grandy, A.S., S. Billings, and D.deB. Richter. 2010. Saving our soils. Front. Ecol. Environ. 8:171. doi:10.1890/1540-9295-8.4.171

Greenland, D.J., and I. Szablocs. 1994. Soil resilience and sustainable land use. $\mathrm{CAB}$ Int., Wallingford, $\mathrm{UK}$.

Grunwald, S. (ed.). 2006. Environmental soil-landscape modeling: Geographic information technologies and pedometrics. CRC Press, Boca Raton, FL.

Grunwald, S. 2009. Multi-criteria characterization of recent digital soil mapping and modeling approaches. Geoderma 152:195-207. doi:10.1016/j. geoderma.2009.06.003

Hilgard, E.W. 1860. Report on the geology and agriculture of the state of Mississippi. E. Barksdale, Jackson, MS.

Hole, F.D. 1974. Wild soils of the Pine-Popple River basin. Trans. Wis. Acad. Sci. Arts Lett. 62:37-50.

Holling, C.S. 1996. Engineering resilience versus ecological resilience. p. 31-43. In P.C. Schulze (ed.) Engineering within ecological constraints. Natl. Acad. Press, Washington, DC.

Hooke, R.LeB. 2000. On the history of humans as geomorphic agents. Geology 28:843-846. doi:10.1130/0091-7613(2000)28<843:OTHOHA>2.0.CO;2

Houghton, R.A. 2007. Balancing the global carbon budget. Annu. Rev. Earth Planet. Sci. 35:313-347. doi:10.1146/annurev.earth.35.031306.140057

Idowu, O., H.M. van Es, G.S. Abawi, D.W. Wolfe, R.R. Schindelbeck, B.N. Moebius-Clune, and B.K. Gugino. 2009. Use of an integrative soil health test for evaluation of soil management impacts. Renewable Agric. Food Syst. 24:214-224. doi:10.1017/S1742170509990068

Janzen, H.H. 2009. Long-term ecological sites: Musings on the future, as seen (dimly) from the past. Global Change Biol. 15:2770-2778. doi:10.1111/ j.1365-2486.2009.01971.x 
Janzen, H.H., P. Fixen, A.J. Franzluebbers, J. Hattey, R.C. Izaurralde, Q.M. Ketterings, D.A. Lobb, and W.H. Schlesinger. 2011. Global prospects rooted in soil science. Soil Sci. Soc. Am. J. 75:1-8. doi:10.2136/sssaj2009.0216

Jenny, H. 1941. Factors of soil formation. McGraw-Hill, New York.

Johnson, D.L. 2005. Reñections on the nature of soil and its biomantle. Ann. Assoc. Am. Geogr. 95:11-31. doi:10.1111/j.1467-8306.2005.00448.x

Johnson, D.W., and S.E. Lindberg. 1992. Atmospheric deposition and nutrient cycling in forest ecosystems. Springer-Verlag, New York.

Marsh, G.P. 1874. The earth as modified by human action. Charles Scribner, New York.

McNeill, J.R., and V. Winiwarter (ed.). 2006. Soils and societies: Perspectives from environmental history. White Horse Press, Isle of Harris, UK.

National Research Council. 2010. Toward sustainable agricultural systems in the 21 st century. Natl. Acad. Press, Washington, DC.

Osborn, F. 1948. Our plundered planet. Faber and Faber, London.

Palm, C.A., P.A. Sanchez, S. Ahamed, and A. Awiti. 2007. Soils: A contemporary perspective. Annu. Rev. Environ. Resour. 32:99-129. doi:10.1146/ annurev.energy.31.020105.100307

Pitman, M.G., and A. Läuchli. 2002. Global impact of salinity and agricultural ecosystems. p. 3-20. In A. Läuchli and U. Lüttge (ed.) Salinity: Environment, plants, molecules. Kluwer Acad. Publ., Dordrecht, the Netherlands.

Postel, S.L., G.C. Daily, and P.R. Ehrlich. 1996. Human appropriation of renewable fresh water. Science 271:785-788. doi:10.1126/science.271.5250.785

Ramankutty, N.,A.T.Evan, C.Monfreda, andJ.A. Foley. 2008. Farming the planet: 1. Geographic distribution of global agricultural lands in the year 2000 . Global Biogeochem. Cycles 22:GB1003. doi:10.1029/2007GB002952

Richardson, C.J. 2008. The Everglades experiments: Lessons for ecosystem restoration. Springer-Verlag, New York.

Richter, D.deB., M. Hofmockel, M.A. Callaham, D.S. Powlson, and P. Smith. 2007. Long-term soil experiments: Keys to managing Earth's rapidly changing ecosystems. Soil Sci. Soc. Am. J.71:266-279. doi:10.2136/sssaj2006.0181

Richter, D. deB., and D. Markewitz. 2001. Understanding soil change. Cambridge Univ. Press, Cambridge, UK.

Richter, D.deB., Jr. 2007. Humanity's transformation of Earth's soil: Pedology's new frontier. Soil Sci. 172:957-967. doi:10.1097/ss.0b013e3181586bb7

Richter, D. deB., Jr., D.H. Jenkins, J.T. Karakash, J. Knight, L.R. McCreery, and K. Nemestothy. 2009. Wood energy in America. Science 323:1432-1433. doi:10.1126/science.1166214

Richter, D. deB., Jr., and M.L. Mobley. 2009. Monitoring the Earth's critical zone. Science 326:1067-1068. doi:10.1126/science.1179117

Robertson, G.P. 2008. Long-term ecological research: Re-inventing network science. Front. Ecol. Environ 6:281. doi:10.1890/15409295(2008)6[281:LERRNS]2.0.CO;2

Robertson, G.P., E.A. Paul, and R.R. Harwood. 2000. Greenhouse gases in intensive agriculture: Contributions of individual gases to the radiative forcing of the atmosphere. Science 289:1922-1925. doi:10.1126/ science.289.5486.1922

Robinson, D.A., and I. Lebron. 2010. On the natural capital and ecosystem services of soils. Ecol. Econ. 70:137-138. doi:10.1016/j.ecolecon.2010.08.012

Robinson, D.A., I. Lebron, and H. Vereecken. 2009. On the definition of the natural capital of soils: A framework for description, evaluation, and monitoring. Soil Sci. Soc. Am. J. 73:1904-1911. doi:10.2136/sssaj2008.0332
Sauer, C.O. 1937. Theme on plant and animal destruction in economic history. p. 121-144. In J. Leighly (ed.) Land and life. Univ. of California Press, Berkeley.

Schaetzl, R.J., and S. Anderson. 2005. Soils: Genesis and geomorphology. Cambridge Univ. Press, Cambridge, UK.

Schillinger, W.F. 2011. Practical lessons for successful long-term cropping systems experiments. Renew. Ag. Food Syst. 26:1-3. doi:10.1017/ S1742170510000359

Seybold, C.A., J.E. Herrick, and J.J. Brejda. 1999. Soil resilience: A fundamental component of soil quality. Soil Sci. 164:224-234. doi:10.1097/00010694199904000-00002

Showers, K.B. 2006. A history of African soil: Perceptions, use and abuse. p. 118-176. In J.R. McNeill and V. Winiwarter (ed.) Soils and societies. White Horse Press, Isle of Harris, UK.

Simonson, R.W. 1959. Outline of a generalized theory of soil genesis. Soil Sci. Soc. Am. Proc. 23:152-156. doi:10.2136/sssaj1959.03615995002300020021x

Smith, P., D.S. Powlson, J.U. Smith, and E.T. Elliott (ed.). 1997. Evaluation and comparison of soil organic matter models using datasets from seven long-term experiments. Geoderma 81:1-225. doi:10.1016/S0016-7061(97)88180-3

Smith, P., D.S. Powlson, J.U. Smith, P.D. Falloon, and K. Coleman. 2000. Meeting Europe's climate change commitments: Quantitative estimates of the potential for carbon mitigation by agriculture. Global Change Biol. 6:525-539. doi:10.1046/j.1365-2486.2000.00331.x

Steinbeck, J. 1940. The grapes of wrath. Viking Press, New York.

Targulian, V.O., and S.V. Goryachkin. 2004. Soil memory: Types of record, carriers, hierarchy and diversity. Rev. Mex. Cienc. Geol. 21:1-8.

Trimble, S.W. 2010. Donald Worster's "Dust Bowl". Aeolian Res. 2:1-4. doi:10.1016/j.aeolia.2009.11.002

Tugel, A.J.,J.E. Herrick, J.R. Brown, M.J. Mausbach, W. Puckett, and K. Hipple. 2005. Soil change, soil survey, and natural resources decision making: A blueprint for action. Soil Sci. Soc. Am. J. 69:738-747. doi:10.2136/sssaj2004.0163

Tugel, A.J., S.A. Wills, and J.E. Herrick. 2008. Soil change guide: Procedures for soil survey and resource inventory. Version 1.1. Natl. Soil Surv. Ctr., Lincoln, NE.

Vernadsky, W.I. 1945. The biosphere and the noösphere. Am. Sci. 33:1-12.

Vitousek, P.M., J.D. Aber, R.W. Howarth, G.E. Likens, P.A. Matson, D.W. Schindler, W.H. Schlesinger, and D.G. Tilman. 1997. Human alteration of the global nitrogen cycle: Sources and consequences. Ecol. Appl. 7:737-750.

Wilding, L.P., and H.S. Lin. 2006. Advancing the frontiers of soil science towards a geoscience. Geoderma 131:257-274. doi:10.1016/j. geoderma.2005.03.028

Wilkinson, B.H. 2005. Humans as geologic agents: A deep-time perspective. Geology 33:161-164. doi:10.1130/G21108.1

Worster, D. 2004. Dust bowl. Oxford Univ. Press, New York.

Yaalon, D.H. 2000. Down to earth. Nature 407:301. doi:10.1038/35030260

Yaalon, D.H. 2007. Human-induced ecosystem and landscape processes always involve soil change. Bioscience 57:918-919. doi:10.1641/B571102

Yaalon, D.H., and B. Yaron. 1966. Framework for man-made soil changes: An outline of metapedo-genesis. Soil Sci. 102:272-278. doi:10.1097/00010694-196610000-00010

Zalasiewicz, J., M. Williams, A. Haywood, and M. Ellis. 2011. The Anthropocene: A new epoch of geologic time? Philos. Trans. R. Soc. A 369:835-841. doi:10.1098/rsta.2010.0339 